\section{Toden kaltaisia jaksoja intellektuellin elämästä}

Suoranta, Juha (2017). C. Wright Millsin sosiologinen elämä. Vastapaino. 300 sivua.

TODEN TOTTA, professori Juha Suoranta on kirjoittanut amerikkalaissosiologi C. Wright Millsistä (1916-1962) inspiroituneen ja lukijaakin inspiroivan elämäkerran. Joissain kirjan arvioissa on kiinnitetty huomiota elämäkerturin vahvaan samastumiseen kohteeseensa. Aiheena oikeastaan onkin kattavan ja perinteisen elämäkerran sijasta Suorannan kuvaus suhteestaan Millsiin, vaikka he eivät tavanneet.

Suoranta tapasi kyllä kirjahankkeensa aikana Millsin perillisiä, jotka kiinnostuivat elämäkerturin tavasta lähestyä isänsä työtä. He antoivat valokuvia ja toivoivat kirjan julkaisua myös englanniksi.

Teostaan ja kohdettaan hyvin kuvaavan moton kirjoittaja valitsi antiikin filosofilta Plutarkhokselta (noin 45-125):

"Ihmisen elämä ei ole tahraton tai täysin nuhteeton. Siksi täydellisimmän kuvan luomiseksi on käytettävä elämän parhaita jaksoja ja pidettävä niitä eniten toden kaltaisena."

\section{YSTÄVÄT KAUKANA, VASTUSTAJAT LÄHELLÄ}

C. Wright Mills näki itsensä ulkopuolisena ja yritti positiostaan käsin ymmärtää tapahtumia samaan aikaan läheltä ja kaukaa.
Häntä ei voi moittia kunnianhimon puutteesta tai sulautumisesta yliopiston harmauteen. Hän halusi muuttaa maailmaa kirjoittamalla ja kirjoittaa ennennäkemättömällä tavalla.

Kun Mills menehtyi liian varhain, hänen kotiyliopistonsa Columbian mahtihenkilöt, kuten Robert Merton (1910-2003) ja Paul Lazarsfeld (1901-1976), eivät edes tulleet muistotilaisuuteen. Lazarsfeld mainitsi eräässä haastattelussa, että Millsin kuolema oli hänelle yhdentekevä, eikä hän katunut Millsille aiheuttamiaan hankaluuksia.

Meksikolaiskirjailija Carlos Fuentes (1928-2012) toisaalta ylisti monien muiden tavoin Millsin totuudellisuutta ja rehellisyyttä. Euroopassa, Latinalaisessa Amerikassa ja joissain kotimaansa vasemmistopiireissä häntä muisteltiin Suorantaa lainaten "rakkaudella".

Millsin maine rakentui alun perin kirjasarjalle, jossa hän tutki valtaa ammattiyhdistysliikkeessä, keskiluokkaa ja valtaeliittiä: The New Men of Power (1948), White Collar (1951) ja The Power Elite (1956). Suomessa hänet tunnetaan parhaiten teoksestaan Sosiologinen mielikuvitus, jonka alkuteos ilmestyi vuonna 1959. Teos herättelee muidenkin kuin sosiologien mielikuvitusta ja ajattelua.

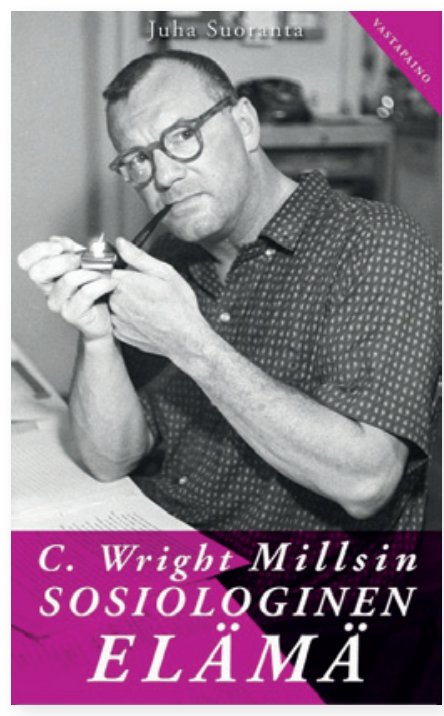

NORSU POSLIINIKAUPASSA

Texasilaisen pikkukaupungin kulttuurisesti köyhissä oloissa varttuneen Millsin siirtyminen New Yorkin toisen polven maahanmuuttajien intellektuellipiireihin oli muutto paratiisiin. Hän oli kuitenkin paratiisissa outo vieras, kuten ensimmäisen polven akateemiset usein. Suoranta kertoo, ettei Mills hallinnut akateemisten ympäristöjen tapakulttuureita, kieltä eikä salaisuuksia.

Oman tiensä raivaajat ovat usein norsuja posliinikaupassa ja syyllistyvät ylilyönteihin. $\mathrm{He}$ eivät liioin kumarra kuvia eivätkä helposti alistu akateemiseen komentoon. Ensimmäisen polven akateemiset maksavat etenemisensä vierauden kokemuksena ja ei-kenenkään-maalle jäämisenä, mitä on hyvin kuvannut sosiologi ja filosofi Georg Simmel (18581918). Suoranta vertaa Millsiä tässä roolissa F. Scott Fitzgeraldin Kultahatun päähenkilöön 


\section{Wright Mills halusi muUttaA}

\section{MAAILMAA KIRJOITTAMALLA.}

Gatsbyyn, jossa Mills tunnistikin jotain samaa kuin itsessään.

\section{AJATTELUN KÄSITYÖLÄINEN}

Millsiä huoletti insinööritieteeksi pelkistyvä yhteiskuntatutkimus vailla moraalisia ja poliittisia pohdintoja. Kriittinen yhteiskuntatutkija ei voi palvella valtaeliitin hallitsemaa järjestelmää eikä tehdä latteaa valtavirtatutkimusta. Jokaisen tutkijan tulee olla oma metodologinsa ja teoreetikkonsa, ammattitaitoinen intellektuelli, ajattelun käsityöläinen.

Tutkimusmenetelmällisten ratkaisujen tulee palvella tärkeiden yhteiskunnallisten ongelmien tunnistamista ja ratkaisua. Todellisen yhteiskuntatutkimuksen kohteena ovat tavallisten ihmisten huolet. Tutkimus voi osoittaa, että yksityiset huolet ovat samalla yhteiskunnan yleisiä ongelmia.

Teorian ja empirian pitää Millsin mukaan tukea ja herätellä toisiaan. Empiria tarkoittaa kerättyjen aineistojen lisäksi henkilökohtaista, itse nähtyä ja kuultua kokemustietoa. Teoria ei ole itseisarvo, vaan sen tarkoitus on auttaa näkemään asioita erilaisista näkökulmista. Faktat eivät puhu puolestaan, vaan niillä on merkitystä vain tietyssä tulkintakehyksessä.

Kun ajatukset, rakenteet ja toiminta ovat historiallisia ja siten muuttuvia ja kehittyviä, niitä voi yrittää ymmärtää vain osana niiden omaa ja yhteiskunnan historiaa.

\section{KERTAKAIKKISEN ELOSSA}

Julkinen intellektuelli Millsistä tuli 1940-luvun mielipidelehtiartikkeliensa sekä 1950-luvun kirjojensa myötä. Postkolonialisti Edward Saidin (1936-2003) mukaan intellektuelli edustaa "kaikkia ihmisiä tai asioita, jotka rutiininomaisesti unohdetaan tai lakaistaan maton alle." Hän ei hyväksy valmiita kliseitä tai tasapaksuja, myötäsukaisia kannanottoja, joita häneltä odotetaan.

Rooli ei ole palkitseva, koska Millsin mukaan intellektuellin vaihtoehdoiksi jää joko elää voimattomana vallan keskusten ulkopuolella, liittyä vallan hännystelijöihin tai riippumattomuutensa myyden asettua julkisuuden palvelukseen.

Poleemisia artikkeleita kirjoittaessaan Mills hioi samalla tiedekirjoittamisen tyyliään. Kirjoittaminen oli hänelle sekä esteettistä toimintaa että tapa ymmärtää itseä. Hyvä kirjoittaja pyrkii rikastamaan yksityistä elämää tekemällä sen kysymyksistä yleisesti kiinnostavia samalla kun hän yrittää sisällyttää inhimillisen merkityksen julkisiin kysymyksiin.
C. Wright Mills tunnustaa kirjeessään:

"Luulen lopulta, että pääsyy siihen, etten ole 'vieraantunut', on kirjoittaminen. Kirjoitettuaan pitkään käsittää, kuinka kertakaikkisen elossa voikaan olla keskellä kirjoittamisen suurta virtaa [--] Kirjoitetuille sivuille ruumiillistuvat elämän kaikkein valppaimmat hetket."

Ehkä moni kirjoittava henkilö voi parhaina hetkinään tunnistaa tämäntapaisen kokemuksen.

\section{JUSSI ONNISMAA}

FT, dosentti, työnohjaajakouluttaja Werka kehitys Oy 